\title{
Problems in Translating Economic Terminology from English into Arabic and vice versa
}

\section{Iman Ahmad Mukhtar Imam}

Faculty of Arts, English Department

Ain Shams University

\author{
Prof. Mustafa Riad \\ Ain Shams University
}

\author{
Dr. Ahmad Elezabi \\ Al Azhar University
}

\begin{abstract}
Economic translation is one of the most meticulous translations that requires extreme attention and concentration. This study aims at exploring and solving the main obstacles in translating economic texts; namely, lexical problems and their impact on translating economic terminology, using the equivalence that is from the same stylistic register (formal versus informal language), frequent use of metaphoric expressions and collocations in business media discourse. To that end, the study introduces first Holmes' Map of translation studies as well as Reiss and Newmark's text typology. In this regard, the researcher links between the text type (formal economic documents or media articles) and the translation method used. Secondly, the study tackles what is meant by economic translation, features governing economic language and the problematic areas in translating economic terminology. Thirdly, it provides lexical analysis of some economic expressions present in a Public Tender and a standardized Auditors' Report, which are different from general texts regarding purpose, target audience and subject matter. Such texts have high level of formality leaving little to interpretation. Finally, the researcher explores the dominant metaphoric expressions and collocations frequently used in business media discourse and suggests their translations.
\end{abstract}

Key words: Economic - Translation - Problems - Terminology

\section{Chapter 1: Introduction}

\subsection{Context of the Study}

Translating economic texts represents a major type of translation as it deals with specialized issues that have to do with finance, commerce, banking, business and the like. Such type of translation is one of the most meticulous and time-consuming translations that requires extreme attention and concentration. The translator should take into account several aspects; most importantly: 
choosing the correct equivalence of the word and using it in the given context, formality levels of the original and target texts, and metaphoric expressions frequently used in media articles.

It is important to draw a line between formal economic writings on the one hand and journalistic economic writings on the other hand. Leech and Svartvik (1975:23) discuss that "[F]ormal language is the type of language we use publically for some serious purposes, for example, in official reports, business letters, regulations, and academic writing". Informal language is generally easier to understand and is used in advertisements and newspaper articles. Leech and Startvik (1975:24) mention that "informal English is now more and more also in written communication kind, for example in newspapers, magazines, advertisements and popular fiction."

White (2003) discusses that there has been a growing interest in the use of metaphors in business and economics; especially within the discipline of English for Specific Purposes. Metaphors are used excessively in business magazines, books and newspapers as they have positive impact on readers' cognition. Koller (2004) mentions that metaphoric expressions in business media texts influence readers' cognition. She explains that by virtue of the nonliteral nature of metaphoric expressions, speakers can hide behind them. Koller hypothesizes that business media discourse is characterized by coherent metaphor clusters. Youssef (2011) advocates that texts written by a vast number of financial analysts and commentators offer strong evidence for the argument that conceptual metaphor is a part of cognition, not just a figure of speech.

Translation theory is the body of knowledge that we have about translation. It aims at establishing the correlation between the original and the translation, generalizing reliance on particular cases that afterwards could be used in performing a translation. Translation theory is concerned with the translation method appropriately used for a certain type of text.

Reiss and Newmark's translation theories on Text Typology contribute a lot to translation studies, but there are some differences as well as similarities in them. Their theory Text Typology provides a new perspective for the study of translation. They argue that text types strongly affect the selection of translation strategy. 
According to Kaussmaul (1995:1),"[t]ranslation is not just an exchange of words and structures, but a communication process that takes into consideration the reader of the translation within a specific culture".

\subsection{Objectives of the Study}

This study aims at exploring and solving the main obstacles in translating economic texts; namely, lexical problems and their impact on translating economic terminology, using the equivalence that is from the same stylistic register (formal versus informal language), frequent use of metaphoric expressions and collocations in business media discourse.

To that end, the study introduces first Holmes' Map of translation studies as well as Reiss and Newmark's text typology. In this regard, the researcher links between the text type (formal economic documents or media articles) and the translation method used. Secondly, the study tackles what is meant by economic translation, features governing economic language and the problematic areas in translating economic terminology. Thirdly, it provides lexical analysis of some economic expressions present in a Public Tender and a standardized Auditors' Report, which are different from general texts regarding purpose, target audience and subject matter. Such texts have high level of formality leaving little to interpretation. Finally, the researcher explores the dominant metaphoric expressions and collocations frequently used in business media discourse and suggests their translations.

\subsection{Research Questions:}

In the light of the previous objectives, it is hoped that this study answers the following questions:

1- How far is the knowledge of translation theory necessary in translating economic texts?

2- What are the linguistic features governing economic language?

3- What are the main problematic areas in translating economic texts?

4- How can the translator deal with specialized expressions and collocations used in economic texts?

5- What are the dominant types of metaphors used in economic media discourse?

6- How far can the Conceptual Metaphor Theory help understand and translate metaphors? 


\subsection{Significance of the Study}

The researcher sheds light on the main obstacles that face the translator in translating economic texts and suggests solutions to overcome such obstacles. The study takes into consideration the cultural element to get a clear meaning of the economic terminology. To the best of the researcher's knowledge, little work is done considering the English/ Arabic translation of the different types of economic writings; be they specialized formal texts or media articles.

\section{Theoretical Framework}

\subsection{Holmes' Map of Translation Studies}

According to Munday (2008), translation is considered today as a discipline. Its study as an academic subject has begun in recent years. This discipline is now generally known as 'translation studies', thanks to the Dutch-based US scholar James S. Holmes. In his paper delivered in 1972, but not widely available until 1988, Holmes describes this discipline as being concerned with the complex problems clustered in translation.

A famous classification of translation concepts and theories has been given by Holmes in his 'map of translation studies'. According to his scheme, translation studies are classified into 'pure' and 'applied' areas. 'Pure' translation studies are subdivided into 'descriptive' and 'theoretical' studies. Descriptive Translation Studies (DTS) are categorized into three orientations: product-oriented, function-oriented, and process-oriented. Theoretical translation studies (TTS) are either 'general' or 'partial'. Partial theories are restricted based on medium, area, rank, text-type, time, or problem. The next branch of translation studies is 'applied' one, referring to the application of translation in other fields and disciplines.

\subsection{Reiss and Newmark's Text Typology}

Text Typology, being a new perspective of translation criteria, plays an active role in the choice of translation strategies and provides implications for addressing the problems of economic translation today. The study of Text Typology that belongs to the budding field of 'Text Linguistics' can be useful for the translator in different ways. Being acquainted with the text-type of the ST and its features, the translator can simply determine the appropriate strategy to be adopted throughout the process of translation. In this respect, Reiss's and 
Newmark's contributions on text typology and translation are influential. Katharina Reiss and Peter Newmark are two translation theorists who have made celebrated contributions to the development of text typology texts.

Munday 2012: 112 states that the classification of text types assists greatly in selecting the most suitable translation approach. He adds that Newmark, Reiss and Nida suggest reasonable matching between text types and the translation approaches. However, there might be more than one text type included in the same paragraph. This will also force the translator to utilize more than one approach in the translation process. Classifying text types definitely gives the translator a guide in matching the text with the suitable translation approach.

In this regard, an essay entitled Translation theories and text types (2012), handles the importance of matching the text type with the translation approach in the field of banking. It provides information about 'Banks Australia', encouraging people to use the services offered by this institution. It uses information and facts about the services to attract readers to the institution. The essay touched on text type classifications from Reiss and Newmark's perspectives. The essay concludes that Reiss and Newmark's text types assist greatly in selecting a translation approach. The essay states that there might be more than one text type included in the one paragraph, which will force the translator to use more than one approach.

\subsection{Economic Translation}

According to Meloyan (2015), translating texts on economics and finance may be considered as a subfield within the field of business translation. It includes translation of documents such as accounting reports; balance sheets, statistical data, bank statements, warranties agreements, reports, bills, invoices, tenders, letters of guarantee, credit applications, technical economic statements, etc.

\subsubsection{Importance of Economic Translation}

Meloyan (2015) mentions that nowadays there is an increasing necessity of translation of economic information due to international business development and growing foreign business markets. Meloyan (2015) maintains that the translation of economic texts plays a pivotal role in international 
business communication. However, the traditional translation criteria cannot be fully applied to the translation of economic texts to the extent that some bilingual translators are incapable of translating economic texts. Therefore, it is of high significance that the present study conducts a systematic research on the translation of economic texts and explores their appropriate translation strategies.

\subsubsection{Features governing Economic Language}

Wang (2017) mentions that in comparison with other texts, features of business texts are distinct. It embraces various text types including business correspondences, advertisements, reports, instructions, agreements or contracts, authoritative statements, bills and forms, etc. In addition, different text type has different styles. Features of economic texts are dealt with in the following subsections as follows.

\subsubsection{Specialized Terminology, Collocations and Fixed Expressions}

What makes an economic text difficult for non-specialized readers and translators is specialized terminology. Dominguez and Rokowski (2002:1) explain that without knowledge of specialized terminology, which includes background knowledge on the concepts behind the term as well as contrastive knowledge, i.e. how the term is used in the target language, it becomes impossible for the translator to produce a good translation.

Baker (1992: 53) argues that register-specific collocations are not simply the set of terms that go with a discipline. They extend far beyond the list of terms that one normally finds in specialized dictionaries and glossaries. For example; in banking terminology, the Arabic equivalence of the fixed expression: 'book keeping' is 'إمساك الدفاتر'.

According to Baker (1992: 47), "at one level, the tendency of certain words to co-occur has to do with their propositional meanings". She explains that the propositional meaning of a word or an utterance arises from the relation between it and what it refers to. When a translation is described as 'inaccurate', it is often attributed to the propositional meaning; for example, cheque is more likely to occur with bank, pay, money and write than with moon, butter, playground or repair.

Baker (1992: 53) points out that "being a native speaker of a language does not automatically mean that the translator can assess the acceptability or 
typicality of register-specific collocations". This is largely why courses in specialized and technical language form an important component of translation training syllabuses. For example, the economic term 'audit' has two different meanings in two different contexts; if it comes in a tax text, 'tax audit' is translated into ' الفحص الضرييى (alfahs eldaribi) but if it comes in a banking text 'bank audit' is translated into 'لهر/جعة البنكية'

Baker (1992: 64) maintains that "[A]s their name suggests, fixed expressions [...] allow little or no variation in form. In this respect, they behave very much like idioms. Unlike idioms however, fixed expressions and proverbs have fairly transparent meanings.

\subsubsection{Formal Language}

Leech and Svartvik (1975: 23) discuss that "[F]ormal language is the type of language we use publically for some serious purpose, for example, in official reports, business letters, regulations, and academic writing”. Informal language is generally easier to understand and is used in advertisements and newspaper articles. Leech and Startvik (1975: 24) mention that "informal English is now more and more also in written communication kind, for example in newspapers, magazines, advertisements and popular fiction." As it is generally easier to understand than formal English, it is often used nowadays in public communication of a popular kind: for example, advertisements and popular newspapers mainly employ a colloquial or informal style.

\subsubsection{Metaphoric Expressions and Collocations in Business Media Discourse}

El-Shazly (2006) mentions that the use of metaphor is a common feature both in literature and in everyday language as it deepens the meaning and makes it more expressive. Fouad (2010) advocates that the importance of metaphor lies in creating a particular perspective of the world, in evaluating social and political issues and in having an emotional impact and persuasive function; i.e., it helps in forming people's opinions and influencing their perception. Metaphors are frequently used by teachers and other professionals to link concepts familiar to learners with concepts which are new or less familiar.

White (2003) attempts to come up with as wide a range as possible of growth collocations in economic books and journals. White (2003) investigates the growth metaphor in economics through a linguistic study of its collocates 
over the last decade primarily in the British press (mainly The Financial Times newspaper) and partly in specialized economic writing.

White (2003, p.136) indicates that "in practice, it can be said that the most noticeable feature of a plant is its inclination for growth and this growth may vary widely under different circumstances". Basically, a scenario of growth would show a cyclic situation within which certain factors would contribute to and foster effective growth (and are therefore positive) while others would impede or diminish it (and are therefore negative).

\subsection{Problematic areas in the Translation of Economic Terminology}

In the light of the features governing economic language in the sub section above, which constitute difficulties in the translation of economic texts, the researcher explores such problematic areas and ways of fixing them aiming at producing a better translation.

\subsubsection{Lexical Problems and their impact on translating Economic Terminology}

Excessive use of specialized terms is one of the main the difficulties in translating economic texts. To overcome this problem, the translator should be aware of the use of specialized monolingual and bilingual dictionaries giving specific focus to monolingual dictionaries as they provide many definitions for the same term, and the translator should be able to choose the correct definition in light of the context in use. But dictionaries are part of the truth as Kaussmaul (1995) sees, so the translator has to search for the missing data through different methods of research on the Internet and read a lot about financial and economic terminology to enrich his schemata (background knowledge) from which he recalls data when needed.

When words belonging to the so-called General English appear next to specific terms and within a specific context, they contain nuances that must be الدخل accounted for in the final translation. For example; synonyms like: income and profit الريح both mean inflow of funds. These terms may seem to be synonyms for non-professional users only as for professional users the difference is apparent and definitely these terms cannot be used interchangeably. It should be further specified that income means money received, especially on a regular basis, for work or through investments while profit means a financial gain, especially the difference between the amount earned and the amount spent in buying, operating, or producing something. 


\subsubsection{Choosing the Equivalence that is from the same Stylistic Register}

Among the obstacles that face the would-be translators also are formality levels. To render an Arabic economic text into English, this requires paying attention to formal and informal languages at both the word and structural levels. A good translator does not reproduce only the content but also the form.

Leech and Startvik (1975) maintain that in English there are many differences in vocabulary between formal and informal language. They mention that some words and expressions are used mainly in formal situations while others are used in neutral or informal situations. For example: compare commence, continue, conclude (formal) with begin, keep up, end (informal). Similarly, التهري الضريبي is translated into tax evasion in formal documents versus tax dodge in informal context.

Concerning grammatical differences between formal and informal English, Leach and Statvik (1975) wrote:

There are also some grammatical differences between formal and informal English: for example, the use of who and whom, and the placing of a preposition at the beginning or at the end of a clause.

Leech and Startvik (1975, p.25) state that "formal written language often goes with an impersonal style; i.e. one in which the speaker does not refer directly to himself or his readers, but avoids the pronouns I, you, we. Some of the common features of impersonal language are passives, sentences beginning with introductory it, and abstract nouns". In addition, Leech and Svartvik (1975) explain that of construction is also preferred (especially in formal English) to the genitive when the modifying noun phrase is long.

Leech and Startvik (1975) mention that in addition to the contracted negative, English has contracted verb forms, which can be tagged on to the subject (usually only if it is a pronoun). There are thus two possible forms of informal negation possible, one with a contracted verb, and one with a contractive negative. Both sets of contracted forms are used in informal English but in formal English, the full forms are used.

Leech and Svartvik (1975, p. 25) mention that the following are linking adverbials of cause or reason meaning because of that or for that reason: 
therefore, thus (rather formal), so (informal), accordingly (formal), hence (formal), consequently (rather formal); the conjunctions while and whereas (more formal) can express contrast between two equivalent ideas.

According to Dudley-Evans and St John (1998), nominalisation is a characteristic of certain more formal genres in business English, such as reports, contracts and some letters. Nominalisation is the use of verbal nouns usually ending in suffixes such as -ation, -ition, -ity, -ment or-ness.

They also mention that many phrasal and prepositional verbs are characteristic of informal style; compare discover, explode, encounter (formal) with find out, blow up, come across (informal). Accordingly, in economic translation, if one is translating the term تصفية in a formal text, it is rendered into English into liquidation (formal) not wind up (informal).

\subsubsection{Frequent Use of Metaphoric Expressions and Collocations in Business Media Discourse}

Figurativeness of metaphoric economic terms in source language should be reflected in translation. Difficulties in translation of metaphorical economic terms and complicated process of finding corresponding concepts in target language are the main obstacles for inter-lingual communication in the sphere of economics. It is hoped that the study helps avoid problems and mistakes while translating metaphorical economic terms.

As mentioned above, metaphoric expressions are used excessively in economic articles. The researcher reviews the most popular contributions in this regard; most importantly: White's (2003) and Koller's (2004) classifications of metaphors in media articles.

\subsubsection{White's (2003) Classification of Metaphors}

According to White (2003), an initial framework for dealing with the understanding of economics could start with the general metaphor: THE ECONOMY IS A LIVING ORGANISM. At this level, the metaphor is available for linguistic realization since one of the classical referential terms to cover the diverse range of economic activities is 'economic life.

White (2003, p.136) mentions that "the productivity of the metaphor will be more obviously available at the basic level". He argues that this level is the plant, animal or human level, giving us the following sub-categorization within the general metaphor just mentioned: THE ECONOMY IS A PLANT or AN ANIMAL or A HUMAN. 
White (2003) argues that all three sub-domains share common or overlapping features so that certain metaphoric expressions could be assigned to two or even three of these. On the other hand, certain attributes are more proper to one or other sub-domain resulting in metaphoric expressions more proper to those fields. Accordingly, White (2003) classifies the different types of metaphors used in business media discourse into four major categories as follows:

\section{A-THE ECONOMY IS A PLANT; \\ B-THE ECONOMY IS AN ANIMAL; \\ C-THE ECONOMY IS A HUMAN BEING; \\ D-THE ECONOMY IS A MECHANICAL PROCESS}

\subsubsection{Conceptual Metaphor Theory (CMT)}

Deignan (2010: 44) mentions that "conceptual metaphor theory, sometimes called cognitive metaphor theory, was developed by researchers within the field of cognitive linguistics. It became widely known with the publication of metaphors we live by by Lakoff and Johnson, in 1980".

Lakoff and Johnson (1980/2003) challenged the traditional view that metaphor was an ornamental figure of speech; a surface linguistic phenomenon, then they claimed that conceptual metaphors structure our thought and behavior; they mention that "metaphor is pervasive in everyday life, not just in language, but in thought and action. Our ordinary conceptual system [...] is fundamentally metaphorical in nature (1980: 3).

Deignan (2010: p.44) maintains that "conceptual metaphor theory proposes metaphor as a link between two domains, termed the 'source' domain and the 'target' domain". Kövecses (2002) argues that most source domains are concrete, whereas most target domains are abstract. Accordingly, conceptual metaphors help facilitate the conceptualization of abstract ideas. Lakoff and Johnson (1980/2003) claim that we understand one concept in terms of another. We tend to structure the less concrete and inherently vaguer concepts (like those for the emotions) in terms of more concrete concepts, which are more clearly delineated in our experience.

According to Lakoff and Johnson (1980/2003), this means that the source domain is the conceptual domain from which we draw metaphorical expressions while the target domain is the conceptual domain that we try to understand; for 
example, in saying THE ECONOMY IS WAR, the domain of war is linked to the domain of economy and features which characterize war are mapped onto economy to describe it. The economy works as a "target domain" that we try to understand in terms of war.

The researcher has used the Conceptual Metaphor Theory (CMT) in translating these metaphoric expressions as this theory opens new horizons for would-be translators for a better understanding of the metaphor and thus, leads to a better translation. In conclusion to this part, the translator should always research and keep himself/herself updated on metaphors that are used in the economic and financial sphere, explore their meanings and try to find their equivalents in the target language.

\section{Methodology}

The researcher adopts Reiss's and Newmark's very important view; namely, matching the text type with the translation approach. Thus, she differentiates between formal economic documents and media articles. Also, she follows Reiss's perception which advocates that economic texts are judged to be 'informative'. Such types of texts should be translated in such a way that the same content in the source text is transferred into the target text.

As to formal economic documents which are characterized by having excessive terminology and fixed expressions, she follows Kaussmaul's (1995) contribution on how to choose the correct equivalence from monolingual and bilingual dictionaries because it is very important to produce the closest natural equivalent to the message in the source language.

As to stylistic register, she follows Leech and Svartvik's (1975) approach that shows the correlation between the degree of formality of situations and the lexical selection.

Concerning media articles, the researcher adopts the Conceptual Metaphor Theory for a better cognition of the metaphoric expressions and collocations that are frequently used in business media discourse in the light of White's and Koller's (2003) classifications of metaphors in economic media articles.

\subsection{Data Collection}

Regarding formal documents, the study aims at examining the translation of three important formal economic texts which include a wide range of specialized terminology and collocations. The first text is an open tender offered 
by the Bank of Alexandria and the researcher provided a suggested translation in the light of consulting different specialized English and Arabic mono-lingual and bi-lingual dictionaries and reading a lot of English and Arabic tenders. The second text is a part of standardized auditors' report of the Bank of Alexandria which is one of the highly formal economic texts. The third one is a short translated text extracted from the Egyptian Exchange (EGX) website which includes a wide range of specific technical terms related to stock markets, some of such terms are available in monolingual or bilingual dictionaries while others are not.

Regarding metaphors in economic media discourse, the data for this study were mainly collected from the Financial Times newspaper, The Economist magazine and the Egyptian Gazette newspaper from which the researcher selected different English economic articles which embody a considerable number of metaphoric expressions under review. In addition, some sentences were selected from economic articles and texts that she came across. The researcher also included data from different mono-lingual and bi-lingual dictionaries to support her translation in this regard.

To stand upon the difficulty in translating metaphors, the researcher also collected data from a huge number of would-be translators (100 homogeneous trainees who were all sit for a translation admission test and got proximate scores). Some of those potential translators studied an economic translation course within a package of translation courses that enable them to attain translation diploma from Ain Shams University-Open Education- while the others study translation to get translation certificate/diploma offered by The American University in Cairo (AUC).

In addition to the above, the researcher asked one of prominent translation centers in Egypt to translate 10 metaphoric sentences carrying 10 metaphoric expressions to see how far metaphors are understood and translated correctly.

\subsection{Procedures}

As to the first part (formal documents), the researcher asked the same would-be translators to translate the above-mentioned formal economic texts to see if there is difficulty in dealing with specialized terminology. The researcher gives them names of some reliable mono lingual and bilingual dictionaries in addition to some online sources from which they can get the data. 
As to the second part (metaphoric expressions), the researcher, at the beginning of the translation course, asked the would-be translators to translate 10 sentences before explaining White's (2003) and Koller's (2004) classification of metaphors or explaining the CMT. In the following session, the researcher collected the sentences from them and checked how they translated the metaphoric expressions. It was found that their translation of metaphors was problematic. The researcher, then, started to explain the CMT and introduced White (2003)'s and Koller's (2004) classifications of metaphors. After explanation, the researcher provided the accurate translation of some sentences and asked them to translate another 23 sentences. The researcher then examined the translation of the above-mentioned sentences to judge the improvement in translating the metaphoric expressions.

In addition, the researcher requested a Language and Translation Center to translate 10 sentences carrying metaphoric expressions that she extracted from different economic articles. It is hypothesized that understanding metaphors is problematic which in turn will lead to inaccurate translation.

\section{Data Analysis}

\section{1. Analysis of Formal Economic Documents}

The study attempts to analyze a formal Public Tender and a Standardized Auditors' Report as to their Lexical Equivalence.

According to the category of text type by Reiss, the source text of the Tender and the Report fall into the informative type, as its content dominates over other elements where readers desire to know the relevant information contained in these documents. Therefore, the target text must accurately and completely convey the ideas of the source text, and it should adopt fixed expressions of target audience to ensure its readability by consulting reliable specialized monolingual and bilingual dictionaries with a view to reproducing the source text surface structure as closely as possible.

\subsubsection{Analyzing and Translating a Formal Public Tender}

$$
\text { يعلن عن طرح المناقصة العامة لتوريد آلات عد نقد ية وآلات تحزيم. }
$$




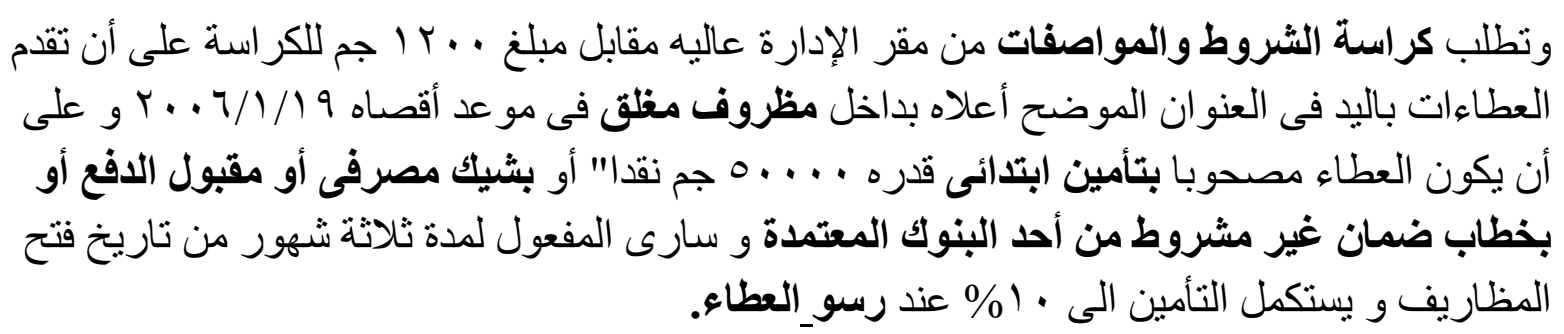

The terms of the source text are translated literally, in the good sense of the word, and is appropriate to the text type. The translator consults first reliable bi-lingual specialized dictionaries such as Al Assiouty Banking and Financial Dictionary. If the term does not exist in bi-lingual specialized dictionaries, he/she has to resort to a mono-lingual specialized dictionary such as Longman Business English Dictionary and try to render a suitable translation in the light of the context. In addition, research on the Internet is very useful. The translator can read similar formal tenders to identify the recurrent economic expressions to enrich his/her background knowledge. For example"مظروف مغلق", most translators think of "closed envelope" which is incorrect. This collocation is found in specialized dictionaries as "sealed envelope". Also, the economic expression "تأمين ابتدائى is problematic as it cannot be translated literally as "preliminary insurance". Here comes the importance of the economic background knowledge of the translator and the context in use; there is a huge difference between the term "insurance" and "bid bond" as an equivalent to such expression. According to Longman Business Dictionary, "insurance" is an arrangement in which a company collects money from a person or organization and in turn agrees to pay them a sum of money if they are involved in an accident, have something stolen, or cause harm or injury to others which is not the intended meaning of the context. But, "bid bond" means: a sum of money that the lowest bidder on a project pays to a developer to cover extra costs that the developer will have if the bidder later refuses to do the work. Therefore, the correct translation is "bid bond" which is considered a collocation at the same time.

Finally, the economic expression "شيك مقبول الدفع cannot be translated into "payable check", rather it should be rendered into "certified check" as found in bilingual specialized dictionaries. Thus, the target text harmony is achieved because the equivalents found in bilingual dictionaries can be used within their target context to activate the meaning we want to express. 
Regarding formality levels, this tender has to be rendered in formal language, i.e. observing the abovementioned rules of formal writing. For example: using of construction instead of the compounding structure when translating خطاب ضمان, i.e. letter of guarantee instead of guarantee letter. Also, using the passive voice: specifications are requested-each bid shall be accompanied by. In formal language, it is not expected to find contracted forms or phrasal verbs; accordingly, they are totally absent. Thus, the translation of the Arabic part of the tender is as follows:

\section{Bank of Alexandria}

\section{Announces:}

Offering the open tender for supplying note counting and binding machines. Specifications are requested from the above-mentioned location for EGP 1200 each, provided that bids are submitted by hand to the afore-mentioned address in sealed envelopes no later than 19/1/2006.

Each bid shall be accompanied by a preliminary bid bond amounting to EGP 50000 in cash, bank or certified cheque or an unconditional letter of guarantee from an authorized bank valid for 3 months as of the date of bid unsealing. Upon bid awarding, the bid bond shall be completed to reach $10 \%$.

\subsubsection{Analyzing and Translating a Standardized Auditors' Report}

The following Arabic document is a part of the auditors' report of Bank of Alexandria. An auditors' report presents a formal opinion issued by auditors based on their audit to the financial statements. The report provides assurance to the shareholders that the financial statements are soundly presented. Such report is issued after reviewing the balance sheet of Bank of Alexandria. It is worth noting however, that All auditors' reports are standardized; i.e., written in the same way except for slight differences.

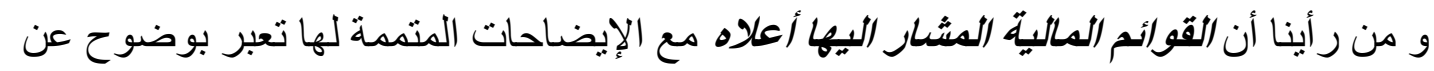

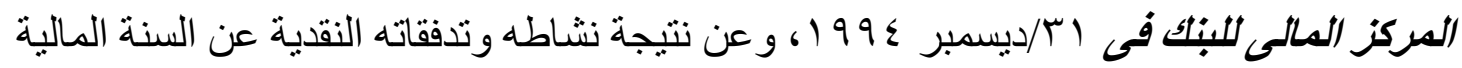

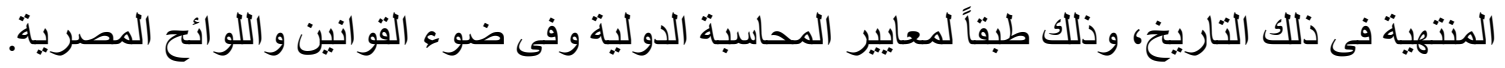

$$
\begin{aligned}
& \text { يمكك البنك حسابات منتظمة تضمنت كل ما نص القانون ونظام البنك على والى وجوب إثباته فيها، }
\end{aligned}
$$

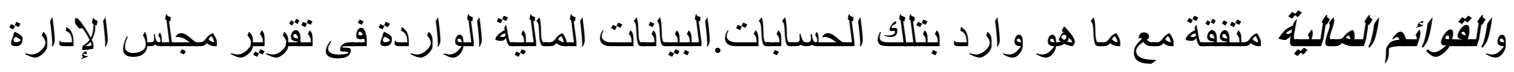

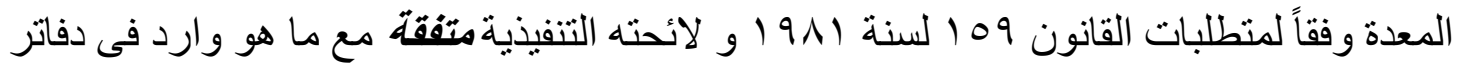

$$
\begin{aligned}
& \text { وسجلات البنكك فى الحدود التى تثبت فيها تلك البيانات بالدفاتر المالية. }
\end{aligned}
$$




\section{مر اقبا الحسابات}

In this paragraph, the following Arabic collocations are translated in a completely different way than the general translation:

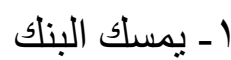

The bank keeps

r

Proper accounts

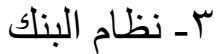

The bank's statutes

The researcher also gives due attention to the importance of rendering the report in a highly formal language; for example:

1- The use of archaic legal terms such as thereof.

2-The following Arabic words are translated into their formal English equivalents; for example:

$$
\text { (متفقة_ المشار اليها أعلاه) }
$$

(In conformity with/in accordance with-abovementioned 3-In formal language, it is not expected to find contracted forms or phrasal verbs. Accordingly, they are totally absent.

5-Nominalization is obvious in the text; for example, management-agreementregulation-presentation.

6-Of-construction is used excessively because it is rather formal than the compounding.

\subsection{Analysis and Translation of Metaphoric Expressions in Media Articles}

The study attempts to analyse and translate metaphoric expressions and collocations that are frequently used in foreign newspapers and magazines from English into Arabic and vice versa.

1- Why did these footwear companies catch a cold? (human).

The domain of human being is linked to the domain of economy and a feature characterizing humans (catch a cold) was mapped onto economy represented in (companies).

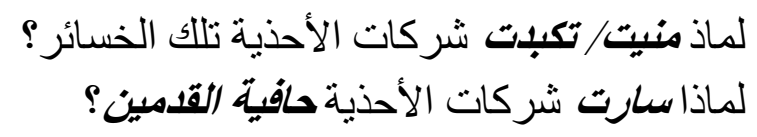

(Replacing the SL image with a similarly functioning standard TL image). 
2- Mexico's Bolsa index fell $4.5 \%$ this weak- its seventh weekly decline, marking the longest drop in almost seven years- on concerns that slower US growth will hit its economy (war).

The domain of war is linked to the domain of economy and a feature characterizing war (hit) was mapped onto economy represented in (growth).

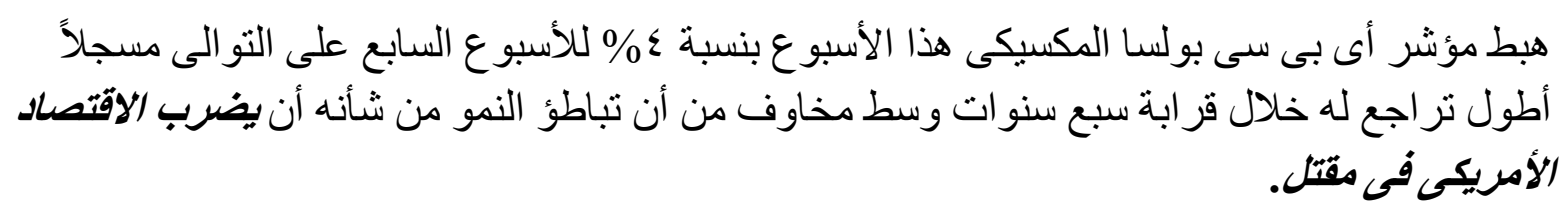

(Replacing the SL image)

3- It is too easy for the prime minister to blame city speculators for blowing his economic policy to smithereens (war).

According to Oxford's Dictionary of Advanced Learners:

To blow means to break something open with explosives. With money, it means to spend or waste a lot of money on something; for example, he inherited over a million dollars and blew it all on drink and gambling. With wind: when the wind or a current of air blows, it is moving; when it blows, the wind is blowing. Smithereens means to destroy something completely by breaking it into small pieces. If something is smashed or blown to smithereens, it breaks into very small pieces (infml).

The domain of war is linked to the domain of economy and features characterizing war (blowing/smithereens) were mapped onto economy represented in (economic policy).

إنه من السهولة بمكان على رئيس الوزر اء لوم مضاربى المدينة على العصف بسياسته الاقتصادية وجعلها هباءً منثوراً.

(Reproducing the same image for blowing/Replacing the SL image with a similarly functioning standard TL image for smithereens).

\section{Conclusions}

\subsection{Findings of the Study}

Translating economic texts is problematic due to the linguistic features governing economic language, namely excessive presence of specialized terms that need to be tackled through consulting reliable specialized dictionaries without ignoring the background knowledge underlying these terms; using formal language in most of the economic texts, which is problematic when translating from Arabic into English; frequent use of metaphors in economic 
media discourse, which has proved to be not just a surface ornamentation of language but an expression of human thought.

The study has explored the main obstacles that may face the translator in translating economic texts and provided solutions for them. The study highlights the significance of translation theory as a pillar for translation as it is the basis upon which the translator can choose the best method of translation. In this regard, the researcher reviewed the most influential theories/trends/approaches that have an impact on translating economic texts; most importantly, Reiss's and Newmark's text typology, Kaussmaul's contribution on the use of dictionaries, Leech's and Svartvich's correlation between the degree of formality and lexical selection, and the Conceptual Metaphor Theory in the light of White's ( $r \ldots r$ ) and Koller's (2004) classifications of metaphors frequently used in business media discourse.

\subsection{Recommendations of the Study}

On the basis of data analysis as well as the major findings of the study, the researcher suggests some recommendations as follows: 1. the translator must be equipped with the elements that affect the meaning of the economic terms as an essential element in the process of translation. It is a fact that the meaning is the main leading reason to failure or success of achieving the appropriate understanding of any particular term. These elements are related to the specific nature of the economic language as well as the economic culture. 2 . The translators must be equipped with the specific features of economic terms by being provided with specific training courses in translating economic texts in order to meet the need of translating such type of language and prepare them to activate their relevant background knowledge in this field. 3. The translator should enhance his ability and his cultural scopes in dealing with the economic terms through many ways, such as reading the topics in this field, getting involved in training programs or courses and so forth. 4. The translator should be familiarized with the economic terms of the source and target languages to be able to recognize the concept which does not have equivalence in the target language to be able to deal with it appropriately.

Text typology which is initially proposed by Reiss and later developed by other scholars is deemed as "a great influence and contribution to the modern translation theory" (Chesteman, 1989:15). It guides us to conduct text analysis 
before getting down to translation. Accordingly, different text types require different translation methods.

\section{References}

Ansaldi, M. (1999). Translation and the Law: Observations of a Law Professor/Translator. Language International.

Baker, M. (1992). In Other Words: a course book on translation. London: Routledge.

Baker, M., \& Saldanha, G. (ed.) (2009). Routledge Encyclopedia of Translation Studies. London and New York: Routledge.

Barkhordar, S. (2018). Read, Comment and Enjoy. Translation Journal.

Brakel, J. (1992). The Complete Description of the Frame Problem, Psycoloquy 3 (60) frame problem 2.

Byrne, J. (2006). Technical Translation: Usability Strategies for Translating Technical Documents. Dordrecht: Springer.

Cambridge Advanced Learner's Dictionary, (2004). Cambridge University Press.

Carter, R. (1998). Vocabulary. Applied Linguistic Perspectives (second edition). London: Routledge.

Catford, J.C. (1965). A Linguistic Theory of Translation, An Essay in Applied Linguistics. London, Oxford University Press.

Charters-Black, J. and Ennis. (2001). A comparative study of metaphor in Spanish and English financial reporting. English for Specific Purposes, 20, 249-266.

Chung, S-F. (2005) MARKET Metaphors: Chinese, English and Malay. Proceedings of PAFLIC 19, the $19^{\text {th }}$ Asia- Pacific Conference on Language, Information and Computation, Taiwan.

Clausner, T. C. and Croft, W. (1997) Productivity and schematicity in metaphor. Cognitive Science, vol.21, no.3, 247-82.

Deignan, A. (2010). The cognitive view of metaphor: conceptual metaphor theory. In L. Cameron and R. Maslen (Eds) Metaphor Analysis: Research Practice in Applied Linguistics, Social sciences and Humanities, pp. 4448. UK: Equinox Publishing Ltd.

Dewaele, j. (1993a). Variation synchronique dans l'interlangue francaise (Unpublished PHD thesis, vrije Universiteit Brussel). 
Dewaele, J. (1993b). Extraversion et richesse lexicale dans deux styles d'interlangue française, I.T.L., Review of Applied Linguistics. 100, 87105.

Dewaele, J. (1994). Extraversion et interlangue, in: Profils d'apprenants, Actes duIXe Colloque international 'Acquisition d'une langue étrangère: perspectives et recherches', Publications de l'Université de SaintEtienne,Saint Etienne, 173-187.

Dewaele, J. (1996a). How to measure formality of speech? A Model of SynchronicVariation, in: Approaches to second language acquisition. Jyväskylä Cross-Language Studies 17, K. Sajavaara \& C. Fairweather (eds.), Jyväskylä, 119-133.

Dewaele, J.-M. (1996b). Variation dans la composition lexicale de styles oraux, I.R.A.L., International Review of Applied Linguistics XXXIV/4, 261-282.

Dobrzyngsk, J. (1995). "Translating metaphor: problems of meaning",Journal of Pragmatics, 24(6), 595-604

Dobrota, J.C., Maftei C. (2009) The Metaphoric Dimension of Economic Text. Romania: Galati University Press.

Dominguez, G.A. and Rokowski, P.E. (2002). Implications in translating economic texts, Translation Journal: Vol. 6 (1), 1-2.

Driscoll, D. and Brizee, A. (2010). Ethics in Public Speaking.www.columbia.edu.

Dudley-Evans, T., \& St John, M. J. (1998) Developments in English for specific purposes: a multi-disciplinary approach. Cambridge: Cambridge University Press.

Dukate, A. (2009). Translation and Ideology: A Critical Reading- Science Direct. Translation, manipulation, and interpreting. Frankfurt, M: Lang. George Scholar.

El-Shazly, A. (2006). A Study of Metaphor in Leila Aboulela's The Translator. English Language and Literature Studies, Ain Shams University, Vol. V (1), 169-177.

Eubanks, P. (2000). A war of words in the discourse of Trade: the rhetorical constitution of metaphor. Carbondale and Edwardsville: Southern Illinois University Press.

Fadaee E. (2011). Translation techniques of figures of speech. International Journal of English and literature: Vol 2 (8), 174-177.

Fouad, M. (2010). Critical Metaphor Theory applied to Egyptian Political discourse. 
Essays in honour of Salwa Kame, pp. 53-58.The Department of English Language and Literature, Cairo University.

Ghazala, H. (1995). Translation as Problems and Solutions: Course-book for university students and trainee translators. Valetta Malta: Elga Publication.

Givón, T. Function, structure and language acquisition, in: The crosslinguistic study of language acquisition: Vol. 1, D.I. Slobin (ed.), Hillsdale, Lawrence Erlbaum, 1008-1025.

Goatly, A. (1997) The Language of Metaphors. London: Routledge.

Halliday, M.A.K. and Hasan, R. (1976). Cohesion in English. London: Longman.

Hatim, B. \& Mason, I. (1990). Discourse and the translator. London and New York: Longman.

Hatim, B. and Munday, J. (2004). An Advanced Resource Book. Psychology Press.

Heylighen, F. (1991) Design of a Hypermedia Interface Translating between Associative and Formal Representations, International Journal of ManMachine Studies 35, 491-515.

Heylighen, F. (1992a). From Complementarity to Bootstrapping of Distinctions: a Reply to Löfgren's Comments on my Proposed 'Structural Language', International Journal of General Systems Vol 20, Number 4.

Heylighen, F. and Dewaele, JM. (1999). Formality of language: definition, measurement and behavioural determinants. Interner Bericht, Center "Leo Apostel", Vrije. Citeseer.

Holmes, James S. (1988). Translated: Papers on Literary Translation and Translation Studies. Amsterdam: Rodopi.

House, J. (2001). Translation quality assessment: Linguistic description versus social evaluation, in META: Translators' Journal.

House, J. (1977). A model for translation quality assessment. Tubingen: Narr.

Karnedi, K. (2015). Translating Economic Texts: A Case Study. ResearchGate 2018.

Kausmaul, P. (1995). Training the translator. Amsterdam: Benjamins.

Koller, V. ( 2004). Metaphor and Gender in Business Media Discourse: a critical cognitive study. UK: Amazon.Co.

Kövecses, Z. (2002) Metaphor: A Practical Introduction. Oxford: Oxford University Press.

Lakoff, G. \& Johnson, M. (1980[2003]). Metaphors We Live By.Chicago: The 
University of Chicago Press.

Lakoff, G. (1987) Women, fire, and dangerous things: What Categories Reveal about the Mind. Chicago: University of Chicago Press.

Leech, G., \& Svartvik, J. (1975). A communicative Grammar of English. London: Longman.

Meloyan, S. (2015). Translation Peculiarities of Economic Texts (On the Basis of Economic Texts Translation Form English into Ukrainian)", International Letters of Social and Humanistic Sciences, Vol. 64, pp. 162165.

Munday, J. (2008). Introducing Translation Studies: Theories and Applications ( 2 ed.). USA and Canada: Routledge.

Munday, J. (2012). Evaluation in Translation: Critical points of translation decision-making. London/New York: Routledge.

Newmark, P. (1988). A Textbook of Translation. UK Prentice Hall.

Newmark, P. (1988). Approaches to Translation. London: Prentice Hall International (UK) Ltd.

Newmark, P. (1985). The Translation of Metaphor, the Ubiquity of Metaphor. Amsterdam: Benjamins.

Nida, E. (1984). On translation. Beijing: Translation Publishing Corp.

Olteanu, A. (2012). Errors and Difficulties in Translating Economic Texts. Editura Sfantul Ierarh Nicole.

Othman, S. A. (2013). Abstract Impact of the Lexical Problems upon Translating of the Economic Terminology. Al-Nasser University's Research Office.

Reiss, K. (1971). Translation Criticism: the Potentials and Limitations. Categories and Criteria for Translation Quality Assessment. Internet Archive HTML5.Uploader 1.6.3.

Reiss, K. (1976). How to Teach Translation: Problems and Perspectives. Research Article.

Reiss, K. (1989). Text types, and translation assessment. In: Chesterman, A. (ed.) (1989). Readings in Translation Theory. Oy Finn Lectura Ab.

Reiss, K. (1971/2004). Type, kind and individuality of text: Decision making in translation. (1971) in L.Venuti (ed) The Translation Studies Reader. $2^{\text {nd }}$ ed. New York: Routledge.

Robert A. and Levy, R. (1967). Relative strength as criterion for investment selection. The Journal of Finance 
Sager, J. (1990). A Practical Course in Terminology Processing. Amsterdam: John Benjamin.

Shakernia, S. (2013). Study of Nida's (formal and dynamic equivalence) and Newmark's (semantic and communicative translation) translating theories on two short stories. Merit Research Journal of Education and Review. Vol. 2(1).

Swan, M. (1995). Practical English Usage. Oxford University Press.

Toury, G. (1995/2004). The nature and role of norms in translation, in L.Venuti (ed) The Translation Studies Reader, 2nd ed. New York: Routledge, pp $204-218$.

Vermeer, H. (1989/2004). Skopos and commission in translatorial action, in L.

Venuti (ed) The Translation Studies Reader, 2nd ed. New York: Routledge, pp 227 - 238.

Venuti, L. (2004). The Translation Studies Reader. New York: Routledge.

Vermeer, Hans J. (1996). A skopos theory of translation (some arguments for and against). Heidelberg.

Wang, Z. (2017). On the characteristics and Translation of Business Texts.

White, M. (2003). Metaphor and economics_the case of growth. English for specific purposes. Madrid: Universidad Politeenica de Madrid.

Youssef, A. (2011). Metaphor in the Bear and Bull Markets: A Corpus-Based Study. Abdel Aziz \& Co. Printing press, Cairo, Egypt. 